\title{
Reconstruction of the Slippery Slope Framework Tax Compliance Model
}

\author{
I Nyoman Darmayasa*, I Made Marsa Arsana, I Made Agus Putrayasa \\ Politeknik Negeri Bali
}

ARTICLE INFO

Article history:

Received 08 November 2021

Revised 10 January 2022

Accepted 01 February 2022

Published 11 February 2021

Keywords:

Conceptual paper

Nation's ideological value

Reconstruction

Slippery slope framework

Tax compliance
ABSTRACT

This study attempts to reconstruct the Slippery Slope Framework (SSF) tax compliance model based on the values of Pancasila as the nation's ideology. This study is a conceptual paper through a literature review. The conceptual based on internalization of the value of Pancasila through historicity, rationality, and actuality. Historically, the SSF compliance model has not fully agreed with the values of Pancasila, which reflects the characteristics of taxpayers in Indonesia. Rationally, the SSF compliance model prioritizes the objective role of tax authorities in their primary task of collecting tax revenues. The reconstruction of the model through the actuality of the nation's ideological value occurs by balancing the role of the tax authority's power with the taxpayers' trust. The reconstruction propositions of the obedience model are based on humanist religious values at the conceptual level. The reconstruction of the SSF compliance model makes the humanist religious assumption the foundation of the tax authority's power as taxpayers' trust increases. The reconstruction model is believed to be able to dynamically transform an antagonistic into a synergistic climate to increase voluntary compliance.

\section{Introduction}

The phenomenon of a low tax rate results in endless jobs. A low tax rate is our collective responsibility. It cannot only be borne by the government or only blamed on taxpayers. The role of the government through biased policies is anticipated by taxpayers. This phenomenon is in line with the indicator that affects the low tax rate, namely, the low level of tax compliance. The phenomenon of low tax compliance has become a global problem (Arnold, 2012) that is being resolved with various approaches. Gamannossi \& Rablen (2020) state that tax avoidance in developed countries costs the government up to $20 \%$ of income tax revenues. Slemrod (2019) states that the enforcement of tax policies using tax audit instruments, information reporting, and financial transaction regulations as an effort to encourage compliance is still a matter of debate. The deterrence economic approach has not been able to realize long-

\footnotetext{
* Corresponding author.

E-Mail address: nyomandarmayasa@pnb.ac.id

ORCID: 0000-0001-6341-6909
} 
term compliance; thus, a more comprehensive approach has emerged, namely, the Slippery Slope Framework (SSF) (Ritsatos, 2014). The SSF approach was introduced by Kirchler et al. (2008) with two dimensions, namely, taxpayer trust in tax authorities and law enforcement. Studies examining SSF have been conducted in many countries (Muehlbacher et al., 2011; Kogler et al., 2013; Mas'ud et al., 2014; Prinz et al., 2014).

Research using the SSF approach in the context of compliance in Indonesia was conducted by Djajanti et al. (2019) and Prastiwi et al. (2019). The perspective on tax compliance in addition to using the SSF approach began to emerge with dimensions of spirituality and religiosity (Sudarma \& Darmayasa, 2017). Further research by Darmayasa et al. (2018) concludes that the perspective of compliance after tax amnesty uses the value of Pancasila. Mangoting (2018) employed a qualitative meta-synthesis approach to interpret the results of tax compliance research and formed conclusions regarding compliance based on mutual commitment between taxpayers and tax authorities. The propositions of this study are still incomplete in nature; thus, further research that provides an integrated framework for a tax compliance model according to the context, space, and time in Indonesia is needed.

This study aims to reconstruct the SSF tax compliance model based on the values of Pancasila as Indonesia's ideology. This study is a conceptual, the reconstruction propositions used is the historicity, rationality, and actuality of Yudi Latif's Pancasila thought (Latif, 2018). This study is different from previous studies that only interpreted the compliance model. This study focused on the value of Indonesia's ideology, which is a self-reflection of taxpayers who balance objectivity with subjectivity. The propositions of the reconstruction of the tax compliance model based on the values of Indonesia's ideology is expected to represent an alternative answer to the phenomenon of the neverending low tax rate.

\section{Literature review}

The tax compliance model was originally introduced by Allingham and Sandmo using an economic approach with the assumption of maximum utility (Allingham \& Sandmo, 1972; Ritsatos, 2014). The compliance model of the economic approach develops along with the development of social norms and taxpayer psychology. In 2007 Erich Kirchler introduced the SSF compliance model with antagonistic and synergistic perceptions (Kirchler et al., 2008). Antagonistic assumptions through the point of view of taxpayers who try to disobey, while the assumption of synergy between tax authorities and taxpayers trust each other (Hofmann et al., 2017).

The tax authority approach with antagonistic assumptions emphasizes power while synergistic assumptions through trust. The SSF model assumes power in the form of taxpayers' perceptions regarding the ability of tax authorities to detect taxpayer non-compliance (Gangl et al., 2015). The assumption of trust is the perception of taxpayers who trust the tax authorities so that taxpayers comply. Emphasis on the power of tax authorities can create an antagonistic climate that arises only by coercive compliance. On the other hand, the perception of taxpayers' trust towards the policies and services of the tax authorities fosters a synergistic climate that is able to create voluntary compliance.

Research by Mas'ud et al. (2014) in Africa found that power and trust affect tax compliance, power has a strong influence on compliance. The SSF compliance model should be adapted to the context and time of day. In the context of Indonesia, it is necessary to approach a tax compliance model that is in accordance with the characteristics of the 
taxpayer. The model of compliance with the approach of social norms, spiritual, and religious is starting to appear (Boone et al., 2013; Darmayasa et al., 2016; Darmayasa \& Aneswari, 2016; Torgler, 2003; Widiastuti et al., 2015) but has not changed the basic assumptions of the SSF tax compliance model. This study proposes the reconstruction of the SSF compliance model with the taxpayer's point of view in accordance with the nation's ideological values, in this study using the Pancasila ideology which is the source of all legal sources in Indonesia (Barlian, 2016; Latief et al., 2018).

\section{Method}

\section{The Conceptual Paper}

This research is a conceptual paper, there are four possibilities in a conceptual paper, consisting of theory synthesis, theory adaptation, typology, and model perspective (Jaakkola, 2020). This research is closely as a model perspective, by building or reconstructing existing tax compliance models. The model perspective bridging a theoretical framework between concepts to pursue prepositions (Cornelissen, 2016). The object of this research is the SSF tax compliance model proposed by Kirchler et al. (2008). The phenomenon of low tax compliance gives the nuance of the absence of a sliding policy that prioritizes the objectivity of tax revenues. The conceptual paper proposes the propositions on the perceived link between the SSF and the values of Indonesia's ideology. The appropriate and suitable paradigm to reconstruct the SSF model based on the Nusantara paradigm.

\section{The Nusantara Paradigm}

The Nusantara paradigm is a self-view of reality based on the main principles, which consist of an integral view of reality, the aim of science is centered on true belief and truth, the identity of the Nusantara, and religiosity and culture. The holistic view of the Nusantara paradigm believes that reality is an integral unit of spiritual material that exists in the past, and future. Therefore, science is aimed at always being able to reconstruct the substance of reality according to religiosity and culture, thus enabling the people of the Nusantara to be able to maintain the human identity of their identity (Ayudia et al., 2019). The problem of modernization lies in the new belief in self-interest (Mulawarman \& Kamayanti, 2018), it becomes very relevant for the SSF model to be reconstructed with a human foundation that balances material and spiritual.

This research used the methods of historicity, rationality, and actuality of Pancasila, which were introduced by Yudi Latif starting in 2011, to create a plenary state. Pancasila, as Indonesia's ideology, contains a historical ontology, theoretical epistemology, and strong conceptual and visual insights (Latif, 2018). Ontologically, historicity is tracing references, extracting the views of informants, and collecting data related to tax compliance. Epistemologically, rationality is the process of rationalizing all the data that have been collected to synthesize research themes towards the reconstruction process. Axiologically, actuality is a process of internalizing the value of Indonesia's ideology as a self-reflection of the taxpayer as the basis for reconstructing the SSF compliance model.

The value of the nation's ideology, which is used to reconstruct the SSF compliance model, reflects the characteristics of taxpayers. This value is the essence of the ideological value of the Indonesian nation, namely, 
Pancasila (Siswoyo, 2013). Pancasila is the source of all sources of law in Indonesia (Barlian, 2016), and taxation is regulated by formal law and material law; thus, it is very appropriate that all policies are based on the values of Pancasila. Pancasila has been used as a methodology in several accounting, auditing, and taxation studies. Salampessy et al. (2018) describe five articles in Pancasila as a methodological sequence. The first article is ontology, the second is epistemology, the third is methodology, the fourth is local wisdom, and the fifth is research axiology. In the context of character building, Amir (2013) and Latief et al. (2018) state that the internalization of the value of Pancasila is a character education effort, in line with researchers' efforts to shape the character of taxpayers and the efforts of tax authorities to create tax awareness.

The research theme begins with the historicity of the SSF tax compliance model. The next theme is the rationality of the thinking of tax authorities and taxpayers on the tax compliance model. The final stage is the reconstruction of the compliance model through three stages of actuality, beginning with the actuality of power, trust, and basic human assumptions in the tax compliance model. The research discussion was compiled simultaneously with data collection following the data presentation technique of the 1994 Milles and Huberman model collaboration guide (Richards \& Hemphill, 2018).

\section{Results and discussion}

\section{The Historicity of the Slippery Slope Framework Tax Compliance Model}

Kirchler et al. (2008) developed an SSF model that describes two dimensions affecting tax compliance. A high level of trust can have a large effect on compliance. When conditions of public trust are low and the authority of the tax authorities is weak, people tend to choose to avoid paying taxes, so the level of compliance is low. The compliance condition changes when there is a change in the level of authority of the tax authority that is not voluntary to a higher level, even though trust is at a low level; and the opportunity to avoid paying taxes decreases due to increased authority, resulting in an increase in tax compliance. However, increasing the authority of tax authorities can lead to lower levels of tax compliance, which creates an antagonistic climate. In contrast to the other two sides, when the authority of the tax authorities is low, the public will follow their own awareness to fulfil their obligations by voluntarily paying taxes, compliance will increase along with changes in public trust and increased trust builds a synergistic climate between the tax authorities and taxpayers. The combination of trust in tax authorities and law enforcement can effectively reduce noncompliance (Kogler et al., 2013; Lisi, 2014; Pickhardt \& Prinz, 2014; Prinz et al., 2014; Gangl et al., 2015; Kaplanoglou \& Rapanos, 2015). Ritsatos (2014) concluded that the SSF model, which is the most comprehensive model, is a synthesis of tax compliance theories.

Recently, the presence of the state in tax collection has involved various elements, one of which is students as tax volunteers who help provide tax reporting education using e-filing (Darmayasa et al., 2020). However, this has not been able to increase voluntary tax compliance, and it requires a more comprehensive perspective of compliance models. The reconstruction of the SSF model in the presence of the state through justice and a concrete form of channelling tax collection for the benefit of the community will build trust. The next stage of reconstruction of the SSF model will use the tax compliance model rationality approach. 


\section{The Rationality of the Tax Compliance Model}

Rationality is an action that prioritizes a rational mindset with considerations of profits and losses. Rationality can be manifested in differences in behaviour. For example, in accounting, the rationality implemented in doing abnormal accounting accrual (Gassouma, 2019). In tax practices, the behaviour between taxpayers in Italy and Denmark is influenced by the risk of tax avoidance (Guerra \& Harrington, 2018). The rationality of the thinking of taxpayers during tax planning not only seeks to minimize tax obligations. To increase the firm value taxpayers tend to implement tax aggressive planning (Fuadah \& Kalsum, 2021). Even entity tax planning is strongly influenced by the operational strategy of each entity (Armstrong et al., 2019). The rationality of tax planning to increase firm value through increasing debt (Modigliani \& Miller, 1963), then the model is modified with long-term debt financing (Shemetov, 2020). The main objective of tax planning is to minimize current tax obligations and future tax liabilities. This can be seen from the positive response of taxpayers to tax administration policy intervention through a reduction in tax rates. This positive response is reflected in the results of the research by Keen and Slemrod (2017) regarding the optimization of tax administration.

The rationality of the thinking is that taxpayers' moves dynamically adjust to the conditions and conditions that benefit the taxpayers. Research related to human characteristics shows that those individuals who have Machiavellianism or prioritize self-interest have different perspectives on tax avoidance and evasion (Pratama, 2017). In principle, there are no people who are willing to pay taxes, and they are always looking for ways not to pay taxes with an economic motivation that includes rationality (Sussman \& Olivola, 2011). The perception of procedural unfairness is affecting non-compliance (Kim \& Lee, 2020). People even campaign for anti-taxation as an expression of themselves that they do not like paying taxes. This behaviour establishes the assumption of homoeconomic humans only.

Furthermore, the researcher explores the views of Mr Tax who provide services to taxpayers. The excerpt of the interview is as follows:

In general, taxpayers must consider the rules that apply when performing tax planning. However, it must be admitted that there are some loopholes in rules that exist. This may be used by taxpayers. On the other hand, there are also taxpayers who do not pay attention to existing regulations in the context of their personal interests, and there is a possibility that weak law enforcement is the background.

The view of Mr Tax provides an understanding that the existing tax regulations still leave several loopholes that allow taxpayers to use them in tax planning. Everything returns to the taxpayers' assumption that if there is personal moral hazard, there is a tendency to pay less attention to tax rules. Mr Tax emphasize that weak law enforcement can be a reason for taxpayers to conduct tax planning, and this increases the tax authority's power.

The researcher investigates the informants' views regarding the antagonistic and synergistic assumptions of the SSF model manifested in the daily relationship between taxpayers and tax authorities. The views of Mr Tax who interact with taxpayers on a daily basis are as follows: 
The Indonesian people are basically people who obey the government, and they are afraid that the government is tough. However, at a certain point, Indonesian society was also known for its formidable resistance, especially hidden resistance. Thus, when authority increases while trust is low, an antagonistic climate normally arises. Likewise, Indonesians are classified as people who have high empathy for others. There are many cases where the persuasive tax approach in some areas is much more successful than just enforcement of the rules in law, and this is the main driver of synergy.

Reflecting on the view of Mr Tax, rationally, the law enforcement of tax authorities that only prioritizes increasing authority will ultimately lead to an antagonistic climate. The SSF model that uses the assumption of homoeconomics has not considered society using passive resistance. The approach to overcoming passive resistance does not only use law enforcement. Persuasive approaches are needed that view taxpayers as equal to tax authorities (Hofmann et al., 2017). This persuasive approach focuses on the values embedded in society, one of which is the value of empathy.

The value of empathy is the human value of the second principle of Pancasila (Salampessy et al., 2018). This value is a value inherited from generation to generation. This value is deeply embedded and needs to be nurtured with a persuasive approach. The SSF model can be balanced with one of the Pancasila values through a humanitarian approach. The SSF model can be embodied by focusing the values of Pancasila in the form of empathy for others.

The SSF tax compliance model is not based on national ideological values. The homoeconomic character that is formed in taxpayers must of course be changed from the point of view by eliminating the selfishness of taxpayers. The SSF compliance model is reconstructed by focusing on religious humanist values. Religious values are able to temper tax evasion attitudes from self -interest perspective (Khalil \& Sidani, 2020). Religious humanist values, which are values that have been embedded in the character of Indonesian society, are the core values of Pancasila. Researchers believe that balancing the element of objectivity inherent in the SSF compliance model with a religious humanist approach can touch the hearts of taxpayers. The next stage is the actuality of the tax compliance model based on the nation's ideological values.

\section{The Actuality of Tax Compliance Model}

The Actuality of Power in the Tax Compliance Model

The first dimension in the SSF model is power. Power can be defined as the power of the tax authority to enforce tax rules and regulations. The strong power in the SSF model tends to create compulsory compliance. However, if the tax authority's power is weak, compliance will be low. To reconstruct the power of the SSF model, the researcher first explores the views of research informants, both Mrs Scholar and Mr Tax. The views of Mrs Scholar are as follows:

The SSF's power cannot control trust because taxpayer trust is influenced by other factors. I mean, when the power of the government or tax authorities is high while trust is low because public services are of poor quality, it will affect the trust. Therefore, aggressive power and low trust create resistance for taxpayers to comply. If 
government products such as laws and their implementation do not have a gap so that they are conducive and fair to help taxpayer businesses and the House of Representatives as a representation of the people's sovereignty in the 4th precept accommodates people's voices, meaning that the formulation of public policies involves the people's voice so that it is created, justice in a democracy will ultimately cause taxpayer trust to arise.

The statement of Mrs. Scholar is interesting that the power in SSF cannot control trust. This point of view is different from the point of view of the tax authority, given that it focuses on a different dimension. The tax authority dimension plays an integral role in running the organization in line with the belief that tax compliance can be realized by increasing the authority of the tax authority (Karakostas \& Zizzo, 2016). Tax authority power is negatively associated with voluntary tax compliance (Siglé et al., 2018). Furthermore, the researcher explores the views of the tax authorities regarding the dimensions of power in the SSF. The responses from Mr Tax show that the tax authority's power in the SSF model can control taxpayer trust. However, it is not as large as the power of other authorities responsible for managing state spending. The following are excerpts from the interviews:

The power that is owned by the tax authorities can be used for two important things. The first is law enforcement, where fair law enforcement will send a message to the public that the tax authorities carry out the mandate to take care of tax revenue. Second, the current tax authorities, which still have little authority to make regulations, can also be used to make better, more transparent, and fairer rules so as to encourage public awareness to be more tax compliant.

The viewpoint of taxation academics regarding power in the SSF model is closely related to building trust. Power without trust only fosters compulsion obedience. The SSF model illustrates that the weaker the power is, the lower the compulsion compliance. The reconstruction of the model that the researcher proposes to present power in the sense of the authority of the authority to enforce taxation rules and regulations is based not only on the objectivity dimension of collecting tax revenues. Power is important in law enforcement and will be effective if it is adjusted to the characteristics of the taxpayers. The heterogeneity of taxpayer characteristics requires a different approach to enforcing tax regulations. According to the results of research by Hofmann et al. (2017), different social demographics between Western societies and other societies result in different responses to tax policy. The SSF model requires adjustment, and a persuasive approach is one of the alternatives. The persuasive approach was acknowledged by Mr Tax in certain societal conditions as being even more successful than the enforcement of authority.

Indonesian society is a religious humanist society. Religion is the first principle of Pancasila, and humanism is the second principle of Pancasila. The approach to a religious humanist society in the embodiment of obedience requires the touch of society. In the dimension of tax authority, it is necessary to develop a religious humanist spirit in exercising its authority, which is reflected in every policy. Fulfilment of a sense of justice, sliding tax rates, and 
simple administration are desired by taxpayers, as concluded by Keen and Slemrod (2017) regarding the policy that the taxpayers responded to be a reduction in tax rates.

Research by Darmayasa et al. (2018) uses the core values of the Pancasila ideology, namely, religious humanists who have succeeded in deconstructing a tax amnesty in accordance with the characteristics of Indonesian society. Furthermore, taxpayers who prioritize religious humanists in following tax amnesty interpret compliance as an act of participation based on sincerity (Sudarma \& Darmayasa, 2017). The next stage after power actuality is the actuality of trust in the SSF compliance model.

\section{The Actuality of Trust in the Tax Compliance Model}

The second dimension in the SSF model is trust. Trust is the trust of taxpayers in the tax authority. Trust in a broad sense is an appreciation of all actions of the tax authorities in conducting their main function to collect tax revenues. The SSF model illustrates that higher taxpayers' trust in the tax authority will foster voluntary compliance. In a low trust condition, taxpayer compliance is also low. The reconstruction of the compliance model that the researcher proposes in this section incorporates the point of view of the taxpayers' trust towards the tax authority.

The core values of the Pancasila ideology that are reflected in the daily lives of the religious humanist community are the foundation for the public's perspective on the tax authority and the perspective of the tax authority on taxpayers. Researchers have the same belief as Mangoting (2018) that tax compliance can be realized from the perspective of the relationship that is built between taxpayers and tax authorities as partners. Furthermore, Sudarma and Darmayasa (2018) using the value of empathy, which is a humanist value, view that the relationship between taxpayers and tax authorities is a reciprocal relationship in which both sides need each other, that relationship based on trust (Cahyonowati et al., 2020). The perspective as partners and reciprocal relationships is based on mutual trust between taxpayers and tax authorities who are able to build trust. The trust that is built between taxpayers and tax authorities in the SSF model is illustrated through the tax authorities' policies that favour taxpayers. A priority fair tax policy is able to encourage the growth of the taxpayers' economy.

The dimension of trust from taxpayers needs to be elaborated by researchers with the perceptions of Mr Tax. Furthermore, to illustrate the actuality of the researchers' trust from the viewpoint of Mr Tax, the following excerpt from the interviews is given:

Cultural aspects of each ethnicity. The weakness of the SSF is that it considers the culture of the people to be homogeneous; meanwhile, Indonesia consists of various cultures, and it can be said that sometimes their characteristics are different from one another. If possible, in the compulsory position, the characteristics of each ethnic group in Indonesia enter our characteristic bell shape, at which point tightening the punishment will only decrease acceptance. Likewise, in the voluntary position, the characteristics of each ethnic group in Indonesia differ from one another.

The view is that the tax authority has led to the reconstruction of human assumptions, those of both tax authorities and taxpayers. The power of the tax authority over a society with people with different characteristics requires 
adjustment according to the conditions of the people's characteristics. Tax authorities' policies in different social conditions should also be adjusted so that trust can be built. Balancing the perspective on the actions and policies of the tax authorities through power and trust requires the actuality of the basic human assumptions in the tax compliance model.

The Actuality of the Basic Human Assumptions in the Tax Compliance Model

The axiology of the tax compliance model is the result of the nature of the homoeconomic man who prioritizes rationality in his daily epistemology so that compliance is only limited to compulsive compliance. Researchers extracted the meaning of Mrs Scholar and Mr Tax regarding basic human assumptions in the SSF model; and homoeconomists tend to prioritize rationality, prioritizing profits or losses (Glaze, 2015; Vigo de Lima \& Guizzo, 2015; Rahim, 2018), likewise in fulfilling tax obligations. The views of Mrs Scholar are as follows:

It seems that the cost-benefit concept is becoming a timeless concept. Even the definition of tax indirectly talks about the compensation that will be received because no taxpayers' payments are free. For example, in Scandinavian countries, their taxes are high, but the quality of life that is paid for by the taxes they pay is also good. This means that taxpayers pay for the quality that will be felt. Building new assumptions is fine, but what should be better understood is whether these assumptions can create trust. For example, assume that only people who earn more than 300 million a year pay taxes. Then, what compensation do those who pay these taxes get so they will always be willing to pay taxes? So, any assumptions that are elaborated on are unlikely to negate the rational aspects of taxpayers as economic people.

There is something interesting from the view of Mrs Scholar that the cost-benefit concept is a timeless concept in taxation. This is in line with the conclusion from Jaya (2019) that the younger generation views that now everything will be beneficial if it provides direct benefits. The core of this difference in viewpoints comes from the basic assumptions of taxpayers in the compliance model. Furthermore, the researcher explores the views of Mr Tax regarding the taxpayers' assumption of maximizing utility according to the classic Allingham and Sandmo (1972) model, whether it is still relevant in modelling tax compliance in Indonesia, as follows:

Utility is an important basis in determining a decision because it is quantitative in nature so that it is more transparent and easier to understand. However, if there are qualitative aspects that are reflected in trust, customer satisfaction, etc., which can complement or can even be presented transparently and can be accounted for objectively, that could be a better choice.

The main objective of this research is to reconstruct the SSF model based on the ideological values of Indonesia. The views related to the reconstruction efforts of researchers conducted on Mrs Scholar and Mr Tax are explored, and their views are as follows: 
It seems like a mix; it is coercive, and it has legitimacy. This means that there is compulsion so that the impression of authority creates an antagonistic climate. For example, taxpayers are afraid to deal with tax authorities. This is an example of an antagonistic climate that arises. Taxpayers always feel they will be blamed, and that will end in sanctions. On the other hand, the government puts forward creating good relations with taxpayers, for example, the existence of a representative account that I think should be a friend, even a tax consultant for taxpayers. Taxpayers face difficulties.

The view of Mrs Scholar leads to the idea that the tax authority exists as a representative account to serve the taxpayers. This is important considering that taxpayers who are treated well can be appreciated for their honesty in calculating, paying, and reporting their tax obligations, thereby encouraging obedient behaviour, even though indirectly (Brockmann et al., 2016). In essence, taxpayers are partners of tax authorities and not opponents, and Casal et al. (2016) stated that social distance between taxpayers and tax authorities affects taxpayer compliance. There needs to be a different perspective to improve compliance considering that taxpayers are seeking a fundamental change in the approach of the tax authority (Nkundabanyanga et al., 2017). It is necessary to establish preventive methods that lead to taxpayer actions that provide incentives to disobey. In others way, the ethical ideology idealism and relativism of tax auditors' conciliatory promotes long term compliance (Nordin et al., 2017). Given that preventive measures are proven to be effective at increasing taxpayer compliance (Hallsworth, 2014), they can become an alternative approach including dialogue between taxpayers and tax authorities (Hermawan et al., 2020).

The educative persuasive approach must involve a comprehensive understanding in the form of understanding from the economic, legal, and psychological perspectives. This view strengthens the actuality of the basic assumptions of the compliance model by viewing taxpayers not only as homoeconomic social beings but also taxpayers who have psychology in accordance with dynamic humanist social norms. The actuality of the basic assumptions of taxpayers and tax authorities in the tax compliance model is a form of linkage in the form of power, trust, and basic human assumptions in the tax compliance model which is the key to the balance of the model towards voluntary compliance.

The final part of this research contains several actualities, namely, the actuality of power, trust, and basic human assumptions. The suggestion of this research is that efforts be made to include the basic assumptions of religious humanists in the SSF model; thus, power and trust will not be at a low level. Religious humanists prioritize sincerity in all actions; and in reconstructing the SSF compliance model, their human foundation is adapted to the characteristics of the local community. The tax authority's authority is reflected in the policies and services that prioritize a humanist approach. The public's reaction to the humanist approach and sliding policies was met with good cooperation and mutual trust in each other's roles. This public reaction fosters trust in the tax authority so that the level of trust is not at a low level.

The actuality of power, trust, and basic assumptions of religious humanists in the SSF model is outlined in the reconstruction of the dynamic moving SSF model. The core value of the Pancasila nation's ideology, namely, religious humanism, is the basis for the support of the SSF model, which is located at the bottom of power and trust such that power and trust are not at a low level. Power and trust go hand in hand as a form of mutual responsibility 
between tax authorities and taxpayers. Given the synergy of law enforcement and trust according to Lisi (2014), Pickhardt and Prinz (2014) were able to reduce noncompliance. The antagonistic climate in the SSF model in the form of power combined with a humanist approach evolves into a synergistic climate. The propositions of the reconstruction of the SSF compliance model with the foundation of humanist religious values on power and trust are presented in Figure 1.

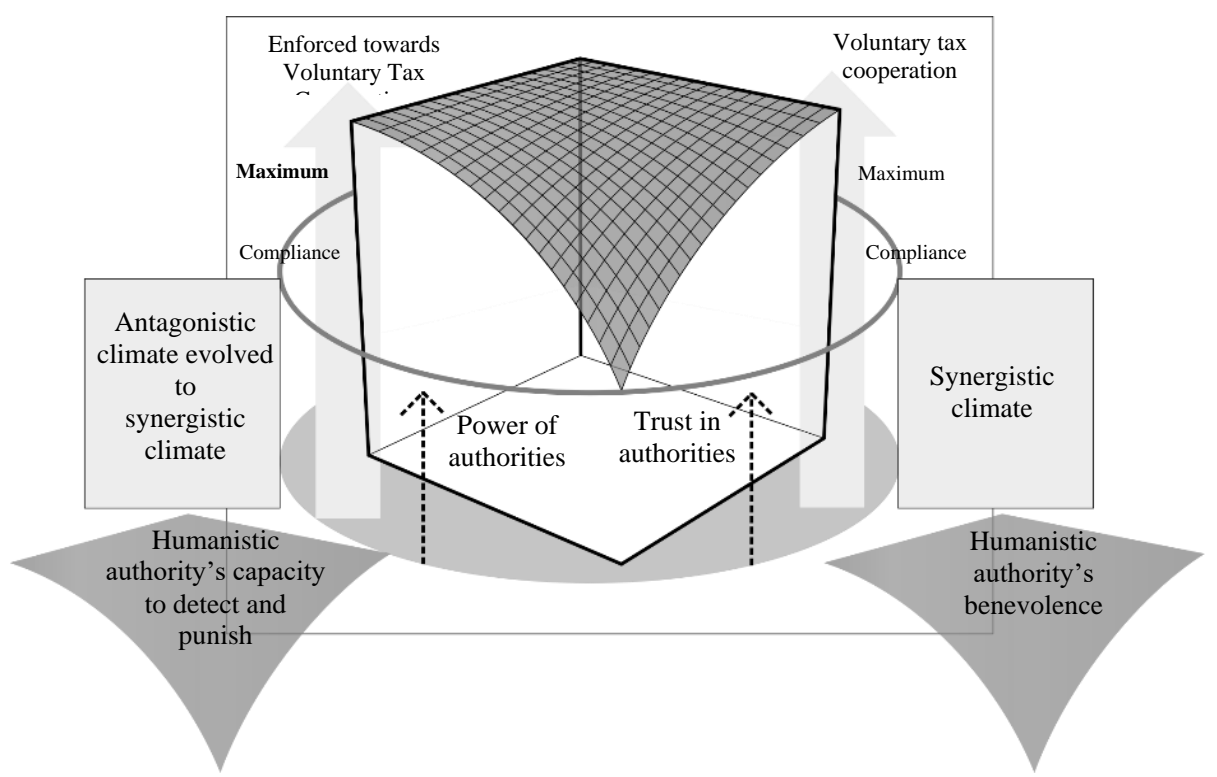

Figure 1. Reconstruction of the tax compliance model based on religious humanist values

\section{Conclusion}

The purpose of this article is to reconstruct the SSF tax compliance model based on the values of Pancasila as Indonesia's ideology. Based on the literature review, it is concluded that the SSF model is not yet fully compatible with the characteristics of taxpayers in Indonesia. Historically, the tax compliance model including economic deterrence, psychological, and SSF approaches has not provided a comprehensive compliance viewpoint. This article emphasizes more objectivity on the role of tax authorities in collecting tax revenues. The rationality of the tax compliance model still includes the assumption of homoeconomic people who prioritize rationality in all actions. Aggressive tax planning is a tangible manifestation of the rationality of basic human assumptions in the SSF model, which is certainly not in accordance with the humanist religious human assumption as a self-reflection of Indonesian taxpayers.

Actuality is the final stage in the reconstruction of the SSF model that consists of three stages. The first stage is the actuality of power. This power is adapted to the enforcement of humanitarian provisions and places with no low level of authority, considering that law enforcement continues to be in tune with the conditions and characteristics of the community. Humanist religious taxpayers respond to the humanist authority of the tax authorities with a sense of trust and the growth of the shared responsibility for the importance of their respective roles. The reconstruction propositions of the SSF model on the humanist religious assumption is a perspective similar to a mirror between tax authorities and taxpayers. Undoubtedly, the antagonistic climate will evolve into a synergistic climate in an effort to increase voluntary compliance. 
This study has limitations, and the reconstruction propositions of the obedience model are based on humanist religious values at only the conceptual level. Further research is needed to implement the propositions of the reconstruction of the tax compliance model at the practical level of tax provisions. Further research efforts using various approaches seeking to ground the conceptual model of adherence at a practical level as an active role in supporting the realization of voluntary compliance is needed.

\section{Acknowledgments}

The authors would like to express their sincerest gratitude to all participants involved in this study and Direktorat Sumber Daya, Direktorat Jenderal Pendidikan Tinggi, Kementerian Pendidikan Kebudayaan, Riset dan Teknologi as a funder of this study.

\section{References}

Allingham, G. M., \& Sandmo, A. (1972). Income Tax Evasion: A Theoretical Analysis. Journal of Public Economics, 1, $323-$ 338. https://doi.org/https://doi.org/10.1016/0047-2727(72)90010-2

Amir, S. (2013). Pancasila as Integration Philosophy of Education And National Character. International Journal of Scientific and Technology Research, 2(1), 54-57. www.ijstr.org

Armstrong, C. S., Glaeser, S., \& Kepler, J. D. (2019). Strategic reactions in corporate tax planning. Journal of Accounting and Economics, 68(1). https://doi.org/10.1016/j.jacceco.2019.03.003

Arnold, J. (2012). Improving the Tax System in Indonesia. In OECD Economics Department Working Papers (No. 998; Issue 998, pp. 1-35). OECD Publishing.

Ayudia, S., Iwan, T., Gugus, I., \& Abdul, G. (2019). A New Methodology to Initiate Islamic Political Economy of Accounting. Eurasia: Economics \& Business, 1(January), 1-9.

Barlian, A. E. A. (2016). Development of Legal System in Indonesia that based on the Value Pancasila. The First International Conference on Law, Economics and Education Muhammadiyah University of Metro, Indonesia, 12-13 November 2016, $29-34$.

Boone, J. P., Khurana, I. K., \& Raman, K. K. (2013). Religiosity and tax avoidance. Journal of the American Taxation Association. https://doi.org/10.2308/atax-50341

Brockmann, H., Genschel, P., \& Seelkopf, L. (2016). Happy taxation: Increasing tax compliance through positive rewards? Journal of Public Policy, 36(3), 381-406. https://doi.org/10.1017/S0143814X15000331

Cahyonowati, N., Ratmono, D., \& Dewayanto, T. (2020). Machiavellianism in a Synergistic Tax Climate. Journal of Asian Finance, Economics and Business, 7(12), 1175-1184. https://doi.org/10.13106/JAFEB.2020.VOL7.NO12.1175

Casal, S., Kogler, C., Mittone, L., \& Kirchler, E. (2016). Tax compliance depends on voice of taxpayers. Journal of Economic Psychology, 56(June), 141-150. https://doi.org/10.1016/j.joep.2016.06.005

Cornelissen, J. (2016). Developing Propositions, A Process Model or A Typology? Addressing The Challenges of Writing Theory Without a Boilerplate. Academy of Management Review, 42(1).

Darmayasa, I. N., \& Aneswari, Y. R. (2016). The Role of Local Wisdom Toward Tax Compliance. Jurnal Akuntansi Multiparadigma, 7(1), 110-119.

Darmayasa, I. N., Sudarma, I. M., Achsin, M., \& Mulawarman, A. D. (2016). Deconstruction of Equitable Tax Amnesty. International Journal of Applied Business and Economic Research, 14(11), 8167-8179.

Darmayasa, I. N., Sudarma, I. M., Achsin, M., \& Mulawarman, A. D. (2018). Constructed interpretation of tax compliance through the historicity, rationality, and actuality of Pancasila (cases in Indonesia). International Journal of Trade and Global Markets, 11(1/2), 67-76. https://doi.org/DOI: 10.1504/IJTGM.2018.092481

Darmayasa, I. N., Wibawa, B. P., \& Nurhayanti, K. (2020). E-filling dan relawan pajak dalam meningkatkan kepatuhan wajib pajak orang pribadi. Jurnal Kajian Akuntansi, 4(2), 208-227. https://doi.org/DOI : 10.33603/jka.v4i2.3949

Djajanti, A., Sutrisno, Subekti, I., \& Nurkholis. (2019). The Role of the Power of Tax Authority in Voluntary Tax Compliance. The Case Study of Jakarta, Indonesia. Journal of Applied Economic Sciences, XIV(Spring, 1(63)), 73-83. https://doi.org/https://doi.org/10.14505/jaes.v14.1(63).07

Fuadah, L. L., \& Kalsum, U. (2021). The Impact of Corporate Social Responsibility on Firm Value: The Role of Tax Aggressiveness in Indonesia. Journal of Asian Finance, Economics and Business, 8(3), 209-216. https://doi.org/10.13106/jafeb.2021.vol8.no3.0209

Gamannossi, D. degl'Innocenti, \& Rablen, M. D. (2020). Tax evasion on a social network. Journal of Economic Behavior and Organization, 169, 79-91. https://doi.org/10.1016/j.jebo.2019.11.001 
Gangl, K., Hofmann, E., \& Kirchler, E. (2015). Tax authorities' interaction with taxpayers: A conception of compliance in social dilemmas by power and trust. New Ideas in Psychology, 37, 13-23. https://doi.org/10.1016/j.newideapsych.2014.12.001

Gassouma, M. S. (2019). Abnormal accounting accrual Management by internal and external Market Discipline: The case of Tunisian banks in the context of the "Arab Spring." ACRN Journal of Finance and Risk Perspectives, 8(1), $106-122$. https://doi.org/10.35944/jofrp.2019.8.1.007

Glaze, S. (2015). Schools Out: Adam Smith and Pre-disciplinary International Political Economy. New Political Economy, 20(5), 679-701. https://doi.org/10.1080/13563467.2014.999757

Guerra, A., \& Harrington, B. (2018). Attitude-behavior consistency in tax compliance: A cross-national comparison. Journal of Economic Behavior and Organization, 156(xxxx), 184-205. https://doi.org/10.1016/j.jebo.2018.10.013

Hallsworth, M. (2014). The use of field experiments to increase tax compliance. Oxford Review of Economic Policy, 30(4), 658679. https://doi.org/10.1093/oxrep/gru034

Hermawan, M. S., Abigail, P., Martowidodjo, Y. H., \& Tohang, V. (2020). Understanding tax amnesty and tax compliance in indonesia: an institutional approach. Journal of Economics, Business, \& Accountancy Ventura, 22(3), 424-434. https://doi.org/10.14414/jebav.v22i3.1810

Hofmann, E., Voracek, M., Bock, C., \& Kirchler, E. (2017). Tax compliance across sociodemographic categories: Meta-analyses of survey studies in 111 countries. Journal of Economic Psychology, 62, 63-71. https://doi.org/10.1016/j.joep.2017.06.005

Jaakkola, E. (2020). Designing conceptual articles: four approaches. AMS Review, 10(1-2), 18-26. https://doi.org/10.1007/s13162-020-00161-0

Jaya, I. M. L. M. (2019). Realita Kesadaran Pajak di Kalangan Generasi Muda (Mahasiswa) Yogyakarta dan Surabaya. Jurnal Ilmiah Akuntansi, 4(2), 161-183. https://doi.org/http://dx.doi.org/10.23887/jia.v4i2.21885

Kaplanoglou, G., \& Rapanos, V. T. (2015). Why Do People Evade Taxes? New Experimental Evidence from Greece. Journal of Behavioral and Experimental Economics, 56, 21-32. https://doi.org/10.1016/j.socec.2015.02.005

Karakostas, A., \& Zizzo, D. J. (2016). Compliance and the power of authority. Journal of Economic Behavior and Organization, 124, 67-80. https://doi.org/10.1016/j.jebo.2015.09.016

Keen, M., \& Slemrod, J. (2017). Optimal tax administration. Journal of Public Economics, 152, $133-142$. https://doi.org/10.1016/j.jpubeco.2017.04.006

Khalil, S., \& Sidani, Y. (2020). The influence of religiosity on tax evasion attitudes in Lebanon. Journal of International Accounting, Auditing and Taxation, 40, 100335. https://doi.org/10.1016/j.intaccaudtax.2020.100335

Kim, H. S., \& Lee, H. A. (2020). Associations among procedural fairness, tax compliance, and tax re-audits. Journal of Asian Finance, Economics and Business, 7(7), 187-198. https://doi.org/10.13106/jafeb.2020.vol7.no7.187

Kirchler, E., Hoelzl, E., \& Wahl, I. (2008). Enforced Versus Voluntary Tax Compliance: The "Slippery Slope” Framework. Journal of Economic Psychology, 29, 210-225. https://doi.org/doi:10.1016/j.joep.2007.05.004

Kogler, C., Batrancea, L., Nichita, A., Pantya, J., Belianin, A., \& Kirchler, E. (2013). Trust and power as determinants of tax compliance: Testing the assumptions of the slippery slope framework in Austria, Hungary, Romania and Russia. Journal of Economic Psychology, 34, 169-180. https://doi.org/https://doi.org/10.1016/j.joep.2012.09.010

Latief, A., Nadir, M., Pangalila, T., Lonto, A. L., Suyanto, T., \& Warsono, M. (2018). Revitalizing the Value of Pancasila in the Development of the Character of Indonesian Citizens. Advances in Social Science, Education and Humanities Research, 226(ICSS 2018), 923-926. https://doi.org/10.2991/icss-18.2018.191

Latif, Y. (2018). The religiosity, nationality, and sociality of pancasila: Toward Pancasila through Soekarno's way. Studia Islamika, 25(2), 207-245. https://doi.org/10.15408/sdi.v25i2.7502

Lisi, G. (2014). The Interaction Between Trust and Power: Effects on Tax Compliance and Macroeconomic Implications. Journal of Behavioral and Experimental Economics, 53, 24-33. https://doi.org/http://dx.doi.org/10.1016/j.socec.2014.07.004

Mangoting, Y. (2018). Quo Vadis Kepatuhan Pajak? Jurnal Akuntansi Multiparadigma, 9(3), 451-470. https://doi.org/10.1515/9783110459418-037

Mas'ud, A., Manaf, N. A. A., \& Saad, N. (2014). Do Trust and Power Moderate Each Other in Relation to Tax Compliance? Procedia - Social and Behavioral Sciences, 164, 49-54. https://doi.org/doi: 10.1016/j.sbspro.2014.11.049

Modigliani, F., \& Miller, M. H. (1963). Corporate Income Taxes and The Cost of Capital: A Correction. The American Economic Review, 53(3), 433-443.

Muehlbacher, S., Kirchler, E., \& Schwarzenberger, H. (2011). Voluntary versus enforced tax compliance: Empirical evidence for the "slippery slope" framework. European Journal of Law and Economics, 32(1), 89-97. https://doi.org/10.1007/s10657-011-9236-9

Mulawarman, A. D., \& Kamayanti, A. (2018). Towards Islamic Accounting Anthropology: How secular anthropology reshaped accounting in Indonesia. Journal of Islamic Accounting and Business Research, 9(4), 629-647.

Nkundabanyanga, S. K., Mvura, P., Nyamuyonjo, D., Opiso, J., \& Nakabuye, Z. (2017). Tax compliance in a developing country: Understanding taxpayers' compliance decision by their perceptions. Journal of Economic Studies, 44(6), 931-957. https://doi.org/10.1108/JES-03-2016-0061

Nordin, Z. S., Muhammad, I., Wahab, K. A., \& Yaakub, N. A. (2017). The personal characteristics that influence tax auditors' conciliatory style: An empirical study. Pertanika Journal of Social Sciences and Humanities, 25(2), 961-976. 
Pickhardt, M., \& Prinz, A. (2014). Behavioral dynamics of tax evasion - A Survey. Journal of Economic Psychology, 40, 1-19. https://doi.org/10.1016/j.joep.2013.08.006

Prastiwi, D., Narsa, I. M., \& Tjaraka, H. (2019). Sintesis Sistem Akuntansi Perpajakan. Jurnal Akuntansi Multiparadigma, 10(2), 276-294. https://doi.org/10.18202/jamal.2019.08.10016

Pratama, A. (2017). Machiavellianism, tax knowledge, and ethical perceptions of tax avoidance: Survey of undergraduate students in West Java, Indonesia. International Journal of Trade and Global Markets, 10(1), 83-90. https://doi.org/DOI: 10.1504/IJTGM.2017.082370

Prinz, A., Muehlbacher, S., \& Kirchler, E. (2014). The Slippery Slope Framework on Tax Compliance: An Attempt to Formalization. Journal of Economic $\quad$ Psychology, $40, \quad 40-34$. https://doi.org/http://dx.doi.org/10.1016/j.joep.2013.04.004

Rahim, E. (2018). Marx-From Hegel and Feuerbach to Adam Smith: A New Synthesis. International Critical Thought, 8(2), 193-209. https://doi.org/10.1080/21598282.2018.1478235

Richards, K. A. R., \& Hemphill, M. A. (2018). A Practical Guide to Collaborative Qualitative Data Analysis. Journal of Teaching in Physical Education, 37(2), 225-231. https://doi.org/https://doi.org/10.1123/jtpe.2017-0084

Ritsatos, T. (2014). Tax Evasion and Compliance: From the Neo Classical Paradigm to Behavioural Economics. Journal of Accounting \& Organizational Change, 10(2), 244-262. https://doi.org/http://dx.doi.org/10.1108/JAOC-07-2012-0059

Salampessy, Z., Triyuwono, I., Irianto, G., \& Hariadi, B. (2018). Pancasila Paradigm: Methodology of Wawasan Nusantara for Accounting of Pancasila. Australasian Accounting, Business and Finance Journal, 12(1), $102-117$. https://doi.org/10.14453/aabfj.v12i1.7

Shemetov, V. V. (2020). On relation between no-arbitrage pricing principle and modigliani-miller propositions. ACRN Journal of Finance and Risk Perspectives, 9(1), 148-174. https://doi.org/10.35944/JOFRP.2020.9.1.012

Siglé, M., Goslinga, S., Speklé, R., van der Hel, L., \& Veldhuizen, R. (2018). Corporate tax compliance: Is a change towards trust-based tax strategies justified? Journal of International Accounting, Auditing and Taxation, 32, 3-16. https://doi.org/10.1016/j.intaccaudtax.2018.06.003

Siswoyo, D. (2013). Philosophy of education in Indonesia: Theory and thoughts of institutionalized state (Pancasila). Asian Social Science, 9(12 SPL ISSUE), 136-143. https://doi.org/10.5539/ass.v9n12p136

Slemrod, J. (2019). Tax compliance and enforcement. Journal of Economic Literature, 57(4), 904-954. https://doi.org/10.1257/jel.20181437

Sudarma, I. M., \& Darmayasa, I. N. (2017). Does Voluntary Tax Compliance Increase After Granting Tax Amnesty? Accounting and Finance Review, 2(3), 11-17. https://ssrn.com/abstract=3008397

Sudarma, I. M., \& Darmayasa, I. N. (2018). The Philosophy Of Tat Twam Asi: The Foundation Of Consciousness Regarding Post-Tax Amnesty (Cases In Indonesia). Journal of Business and Finance in Emerging Markets, 2(1), 153-160. https://doi.org/https://doi.org/10.32770/jbfem.vol1153-160

Sussman, A. B., \& Olivola, C. Y. (2011). Axe the Tax: Taxes Are Disliked More than Equivalent Costs. Journal of Marketing Research, 48(SPL), S91-S101. https://doi.org/10.1509/jmkr.48.SPL.S91

Torgler, B. (2003). Tax Morale: Theory And Empirical Analysis Of Tax Compliance. University Basel.

Vigo de Lima, I., \& Guizzo, D. (2015). An Archaeology of Adam Smith‘s Epistemic Context. Review of Political Economy, 27(4), 585-605. https://doi.org/10.1080/09538259.2015.1082819

Widiastuti, N. P. E., Sukoharsono, E. G., Irianto, G., \& Baridwan, Z. (2015). Yadnya - Hinduism Philosophy to Achieve Spiritual Awareness of SME Owners as Taxpayers: A Literary Discourse. International Journal of Business and Management Invention, 4(5), 38-43.

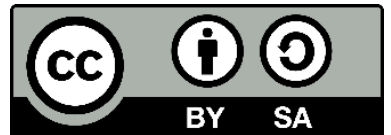

(C) 2022 by the authors. Licensee ACRN Publishing, Austria, Editor in Chief Prof. Dr. Othmar M. Lehner. This article is an open access article distributed under the terms and conditions of the Creative Commons Attribution (CC BY SA) license (https://creativecommons.org/licenses/by-sa/4.0/) 